Jurnal Pendidikan Dasar Indonesia is licensed under

A Creative Commons Attribution-Non Commercial 4.0 International License

\title{
Analisis Kebutuhan Pengembangan Bahan Ajar Elektronik di Era Pandemi Covid-19
}

\author{
Mohammad Afifulloh' ${ }^{1)}$, Bagus Cahyanto ${ }^{2)}$ \\ 1) Pendidikan Guru Madrasah Ibtidaiyah, University of Islam Malang, Malang, Indonesia \\ E-mail:mohammad.afifulloh@unisma.ac.id \\ 2) Pendidikan Guru Madrasah Ibtidaiyah, University of Islam Malang, Malang, Indonesia \\ E-mail: baguscahyanto@unisma.ac.id
}

\begin{abstract}
Adanya perkembangan ilmu pengetahuan dan teknologi yang bergerak begitu cepat ikut mempengaruhi praktik pembelajaran di pendidikan tinggi. Saat ini pembelajaran dapat dilakukan tidak harus dalam waktu dan tempat yang sama. Hal ini tentu harus didukung bahan ajar yang dapat memfasilitasi kebutuhan pembelajaran online, untuk itu perlu dikembangkan bahan ajar elektronik untuk membantu mahasiswa dalam pembelajaran secara online. Pada penelitian ini peneliti membatasi pada tahap analisis kebutuhan saja, sehingga tujuan dari penelitian ini untuk menggali informasi terkait kebutuhan pengembangan bahan ajar elektronik sesuai keadaan dilapangan yang nantinya untuk dijadikan landasan dalam proses pengembangan produk. Teknik pengumpulan data yang digunakan berupa kuesioner analisis kebutuhan pengembangan bahan ajar elektronik yang dikembangkan berdasarkan indikator-indikator analysis pada tahap model pengembangan ADDIE. Angket tersebut dianalisis menggunakan analisis deskriptif berdasarkan hasil dari responden yang meliputi (a) analisis karakteristik pebelajar (b) analisis sumber daya, dan (c) analisis tujuan pembelajaran. Berdasarkan hasil analisis kebutuhan menunjukkan bahwa analisis karakteristik pebelajar menunjukkan bahwa $87,03 \%$ mahasiswa memiliki pengetahuan terhadap penggunaan bahan ajar elektronik dalam pembelajaran, 94,44\% mahasiswa memiliki pandangan yang positif terhadap pemanfaatan bahan ajar elektronik dalam pembelajaran, $100 \%$ mahasiswa memiliki kebiasaan menggunakan digital resource dalam kehidupan sehari-hari, 100\% mahasiswa memiliki ketertarikan terhadap penggunaan bahan ajar elektronik dalam pembelajaran, serta 94,44\% Memiliki ketertarikan terhadap bahan ajar elektronik untuk menumbuhkan kemandirian belajar. Sedangkan hasil analisis sumber daya menunjukkan $87,03 \%$ mahasiswa mengetahui bahwa substansi konten bahan ajar tersedia di jurnal, buku, dan sumber-sumber yang ada kaitannya dengan materi perkuliahan, 100\% mahasiswa memiliki laptop/gadget yang dapat mendukung pemanfaatan bahan ajar elektronik, dan 100\% mahasiswa memiliki pemahaman terhadap penggunaan digital teknologi dalam pembelajaran.
\end{abstract}

Keywords: bahan ajar elektronik, analisis kebutuhan, pembelajaran di masa pandemi

\section{PENDAHULUAN}

Perkembangan teknologi yang begitu pesat membawa berbagai perubahan pada semua aspek kehidupan salah satunya bidang pendidikan. Teknologi secara umum dapat dimaknai sebagai sebuah sarana dan prasarana yang dapat membantu kelangsungan hidup dan kenyamanan manusia. Seiring perkembangannya, teknologi digital telah mengalami perluasan makna sehingga dapat menjangkau semua aspek kehidupan. Teknologi digital mempunyai potensi dan peluang strategis untuk berperan dan mendukung keberhasilan pendidikan dan pembelajaran di perguruan tinggi (Hills \& Thomas, 2019). Selain itu teknologi digital juga dapat menjadi solusi untuk memberikan sebuah pengalaman belajar baru di luar kelas dan mengekspresikan bentuk pemahaman yang berpusat pada pembangunan makna sesuai konstruksi mahasiswa (Cuthbertson et al., 2007; Hills \& Thomas, 2019).
Era globalisasi menunjukkan perkembangan teknologi informasi yang begitu pesat. Keadaan seperti ini tentu tidak dapat dihindari pengaruhnya, lebih khususnya pengaruh terhadap dunia pendidikan. Tuntutan zaman modern seperti saat ini membuat semua elemen pendidikan untuk selalu menyesuaikan perkembangan teknologi informasi. Hal tersebut dilakukan sebagai bentuk usaha untuk meningkatkan mutu pendidikan, terutama penyesuaian penggunaan teknologi informasi dalam pembelajaran di pendidikan tinggi. Dalam keadaan yang sangat dinamis seperti saat ini kegiatan pembelajaran memerlukan sebuah inovasi dan kreativitas, sehingga pembelajaran menjadi lebih berwarna (Baloran, 2020; Karademir et al., 2019). Perkembangan teknologi informasi seharusnya tidak hanya sebagai realitas perubahan zaman namun harus disikapi sebagai sebuah peluang strategis dalam upaya mendorong pembelajaran yang menarik bagi mahasiswa. 
Salah satu potensi strategis dalam perkembangan teknologi digital yaitu proses pembelajaran dapat dilakukan dengan menggunakan bahan ajar berbasis teknologi digital, media komunikasi, software, internet, e-mail, dan lain sebagainya. Pola komunikasi dan interaksi antara dosen dan mahasiswa dapat dikembangkan tidak hanya dilakukan melalui tatap muka, namun juga dapat dilakukan dengan menggunakan bantuan teknologi digital. Dengan adanya teknologi digital ini, dosen lebih mudah memberikan layanan tanpa harus berhadapan secara langsung dengan mahasiswa (Baloran, 2020; Karademir et al., 2019). Demikian pula perkembangan teknologi informasi ini juga dapat dirasakan manfaatnya oleh mahasiswa, mereka akan lebih mudah dalam mendapatkan informasi dalam skala yang luas dari berbagai sumber yang akurat.

Beberapa tahun terakhir ini telah banyak berkembang pembelajaran dalam jaringan atau daring. Pembelajaran daring yaitu proses pembelajaran yang dilakukan secara online menggunakan bantuan akses internet. Belakang ini model pembelajaran lain yang semakin populer adalah e-learning, dimana pembelajaran dapat dilakukan dengan menggunakan bantuan teknologi digital khususnya berupa internet sehingga memungkinkan mahasiswa dapat belajar dimanapun dan kapanpun. Pembelajaran dalam jaringan dapat mendukung pembelajaran jarak jauh (Thurston, 2005), membantu meningkatkan kemandirian dan motivasi belajar mahasiswa (Zimmerman \& Kulikowich, 2016).

Peran e-learning dalam proses pembelajaran secara umum dapat dikelompokkan menjadi dua, yaitu komplementer dan substitusi. Peran komplementer dapat diartikan sebagai sebuah pembelajaran pertemuan tatap muka yang dikombinasikan dengan model interaksi belajar dengan bantuan teknologi. Berbeda dengan peran substitusi, peran substitusi dapat diartikan sebagai sebuah pembelajaran yang sebagian besar proses pembelajarannya dilaksanakan dengan bantuan teknologi. Adanya perkembangan ilmu pengetahuan dan teknologi banyak membuka peluang untuk penyelenggaraan pendidikan jarak jauh, dimana bahan ajar elektronik memiliki peran besar dalam menentukan keberhasilan pembelajaran (Czajka \& McConnell, 2019). Artinya, bahan ajar elektronik sangat dibutuhkan keberadaannya di tengah-tengah praktik pembelajaran secara online walaupun dosen perlu melakukan analisis terhadap kebutuhan di lapangan.

Penelitian yang dilakukan Putrawangsa \& Hasanah (2018) menunjukkan bahwa teknologi digital dapat meningkatkan pemahaman konseptual dan mengembangkan kemampuan intuisi. Dalam penelitiannya juga ditemukan bahwa fungsi didaktik dari teknologi digital dalam pembelajaran meliputi (a) fungsi teknologi sebagai pendukung dan alternatif pengganti media pembelajaran, (b) fungsi teknologi sebagai lingkungan belajar dalam mengasah keterampilan, serta (c) fungsi teknologi digital sebagai media untuk mengembangkan pemahaman konseptual. Artinya untuk mempersiapkan sumber daya manusia yang siap memasuki era masyarakat berbasis pengetahuan (knowledge-based-society), maka sebuah keniscayaan untuk mengintegrasikan digital teknologi dalam pembelajaran. Tantangan dosen di era saat ini setidaknya memiliki empat kompetensi diantaranya (a) mengetahui penggunaan digital serta penerapannya, (b) memiliki kompetensi kepemimpinan yang mampu mengarahkan mahasiswa memiliki keterampilan teknologi, (c) memiliki kemampuan untuk memprediksi arah perubahan zaman serta strategi menghadapinya, dan (d) mampu memunculkan ide, inovasi, serta kreativitas berkarya (Harto, 2018).

Saat ini di berbagai belahan dunia, tengah dikejutkan dengan fenomena pandemi Covid-19. Pandemi Covid 19 ini telah membawa dampak pada berbagai bidang, terlebih pada bidang pendidikan. Kondisi pandemi telah memperkuat posisi pembelajaran daring sebagai salah satu alternatif di pendidikan tinggi. Sistem pembelajaran online yang berbasis teknologi tentu mengharuskan lembaga pendidikan, dosen, dan mahasiswa agar cakap teknologi. Penyebaran covid-19 telah menyebabkan perubahan pola interaksi pembelajaran (Murphy, 2020), dan membutuhkan bahan ajar yang dapat meningkatkan kemandirian mahasiswa (Marhayani, 2020). Hal ini harus dilakukan untuk percepatan transformasi teknologi digital dalam pembelajaran. Bahan ajar diharapkan dapat dikembangkan secara elektronik, agar dapat mendorong terwujudnya pembelajaran efektif, mandiri (Hobbs, 1987; Wilson, 2018) serta membantu mahasiswa memperoleh keterampilan yang diperlukan (Busstra et al., 2008; Coughlan \& Swift, 2011).

Penelitian ini bertujuan untuk menganalisis kebutuhan dalam pengembangan bahan ajar elektronik yang sesuai dengan karakteristik mahasiswa dan sarpras yang ada. Hal ini sangat diperlukan sebagai informasi awal dalam pengembangan sebuah produk bahan ajar. Selain itu hasil analisis ini memiliki manfaat bagi dosen dalam menentukan perlakuan apa yang tepat dalam praktik pembelajaran dalam meningkatkan kemampuan memahami materi pada mata kuliah tertentu. Pada penelitian ini, peneliti membatasi hanya pada tahap analisis kebutuhan, karena proses analisis merupakan tahap penting dalam merancang suatu produk yang hasilnya dapat kita jadikan landasan dalam proses pengembangan produk yang sesuai kebutuhan di lapangan.

\section{METODE}

Penelitian ini menggunakan rancangan model penelitian dan pengembangan (R\&D). Adapun prosedur atau langkah pengembangannya menggunakan model pengembangan dengan pendekatan ADDIE (Branch, 2010). Model pengembangan ADDIE memiliki prosedur yang meliputi beberapa langkah diantaranya (a) analysis, (b) design, (c) development, (d) implementation, dan (e) evaluation.

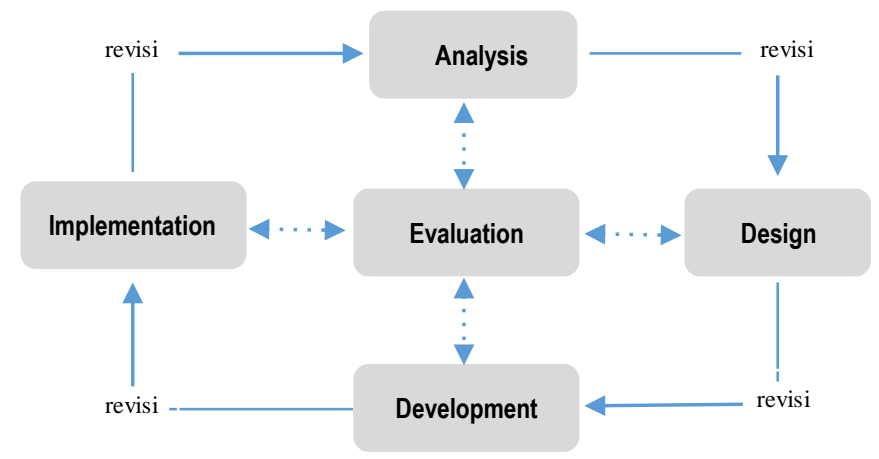




\section{Gambar 1. Prosedur Pengembangan ADDIE (Branch, 2010)}

Pada penelitian, peneliti fokus pada analisis kebutuhan yang dikembangkan berdasarkan tahap pertama model pengembangan ADDIE yaitu analysis. Tujuan utama penelitian ini adalah untuk mengetahui produk yang cocok dikembangkan sesuai dengan kebutuhan mahasiswa dan permasalahan yang ditemukan dalam pembelajaran khususnya pada mata kuliah pembelajaran terpadu. Penelitian ini dilakukan pada bulan Maret 2020. Subjek penelitian diambil dari 54 mahasiswa Pendidikan Guru Madrasah Ibtidaiyah di Fakultas Agama Islam Universitas Islam Malang pada tahun akademik 2019/2020.

Teknik pengumpulan data yang digunakan berupa angket (kuesioner) analisis kebutuhan pengembangan bahan ajar elektronik yang dikembangkan berdasarkan indikatorindikator analysis pada tahap model pengembangan ADDIE. Angket tersebut disebarkan kepada responden melalui google form. Data yang diperoleh kemudian dianalisis menggunakan analisis deskriptif berdasarkan hasil jumlah jawaban yang diberikan oleh responden.

\section{HASIL DAN PEMBAHASAN}

Sebuah penelitian pengembangan didasarkan atas kebutuhan di lapangan, kebutuhan yang dimaksudkan adalah bentuk kesenjangan antara kondisi yang diinginkan dengan kondisi nyata saat ini, sehingga untuk mengatasi kesenjangan tersebut diperlukan peningkatan kualitas pembelajaran melalui kegiatan analisis kebutuhan. Analisis kebutuhan bahan ajar elektronik pada penelitian ini merupakan analisis kebutuhan bahan ajar untuk mengetahui jenis dan model bahan ajar yang dibutuhkan oleh mahasiswa dalam rangka peningkatan kualitas pembelajaran. Untuk menghasilkan bahan ajar yang baik maka di awal diperlukan analisis kebutuhan untuk mengumpulkan informasi dan menganalisis kebutuhan mahasiswa.

Pengumpulan informasi kebutuhan terhadap pengembangan produk berupa bahan ajar elektronik pada mata kuliah Pembelajaran Terpadu ini dilakukan dengan menyebarkan angket kuesioner kepada responden tentang kebutuhan dilapangan. Dari hasil angket tersebut kemudian diuraikan dan dianalisis seluruh kebutuhan mahasiswa sebagai langkah awal dalam mengembangkan produk berupa bahan ajar elektronik untuk mata kuliah Pembelajaran Terpadu pada program studi Pendidikan Guru Madrasah Ibtidaiyah Fakultas Agama Islam Universitas Islam Malang. Pada model pengembangan ADDIE, terdapat beberapa bagian penting yang perlu dianalisis diantaranya (a) menganalisis karakteristik pebelajar (b) menganalisis sumber daya, dan (c) menganalisis tujuan pembelajaran. Berdasarkan hasil analisis kebutuhan yang telah dilakukan peneliti, diperoleh data sebagai berikut.

\section{Analisis Karakteristik Pebelajar}

Analisis karakteristik pebelajar berisi tentang analisis pengetahuan awal mahasiswa tentang konten, persepsi terhadap konten, kemampuan awal, motivasi, potensi sistem penyajian, gaya belajar, serta karakteristik kelompok yang dilakukan dengan menggunakan kuesioner melalui google form. Substansi karakteristik pebelajar ditawarkan kepada mahasiswa dan menjadi pilihan jawaban di kuesioner yang disebar. Responden diberikan link yang terintegrasi ke google form, lalu memilih opsi jawaban yang telah disediakan. Adapun hasil analisis kebutuhan kepada mahasiswa secara rinci dapat dilihat pada tabel 1 berikut.

Tabel 1

Analisis Karakteristik Pebelajar

\begin{tabular}{|c|c|c|c|}
\hline No & $\begin{array}{l}\text { Variabel } \\
\text { Analisis }\end{array}$ & Karakteristik Pebelajar & Persentase \\
\hline 1 & $\begin{array}{l}\text { Pengetahuan } \\
\text { pada Konten }\end{array}$ & $\begin{array}{l}\text { Memiliki pengetahuan } \\
\text { terhadap penggunaan } \\
\text { bahan ajar elektronik } \\
\text { dalam pembelajaran }\end{array}$ & $87,03 \%$ \\
\hline 2 & $\begin{array}{l}\text { Persepsi } \\
\text { terhadap } \\
\text { Konten }\end{array}$ & $\begin{array}{l}\text { Memiliki pandangan yang } \\
\text { positif terhadap } \\
\text { pemanfaatan bahan ajar } \\
\text { elektronik dalam } \\
\text { pembelajaran }\end{array}$ & $94,44 \%$ \\
\hline 3 & $\begin{array}{l}\text { Level } \\
\text { Kemampuan }\end{array}$ & $\begin{array}{l}\text { Memiliki kebiasaan } \\
\text { menggunanakan digital } \\
\text { resource dalam kehidupan } \\
\text { sehari-hari }\end{array}$ & $100 \%$ \\
\hline 4 & Motivasi & $\begin{array}{l}\text { Memiliki ketertarikan } \\
\text { terhadap penggunaan } \\
\text { bahan ajar elektronik } \\
\text { dalam pembelajaran }\end{array}$ & $100 \%$ \\
\hline 5 & $\begin{array}{l}\text { Potensi Sistem } \\
\text { Penyajian }\end{array}$ & $\begin{array}{l}\text { Memiliki ketertarikan } \\
\text { terhadap bahan ajar } \\
\text { elektronik untuk } \\
\text { menumbuhkan } \\
\text { kemandirian belajar }\end{array}$ & $94,44 \%$ \\
\hline
\end{tabular}

Analisis karakteristik pebelajar dilakukan dengan cara menyebarkan angket kuesioner kepada responden. Dari hasil analisis diketahui bahwa mahasiswa telah memiliki pengetahuan terhadap penggunaan bahan ajar elektronik dalam pembelajaran sebanyak $87,03 \%$, memiliki pandangan yang positif terhadap pemanfaatan bahan ajar elektronik dalam pembelajaran sebanyak 94,44\%, memiliki kebiasaan menggunanakan digital resource dalam kehidupan sehari-hari sebanyak $100 \%$, memiliki ketertarikan terhadap penggunaan bahan ajar elektronik dalam pembelajaran sebanyak $100 \%$, dan memiliki ketertarikan terhadap bahan ajar elektronik untuk menumbuhkan kemandirian belajar sebanyak $100 \%$.

\section{Analisis Sumber Daya}

Analisis sumber daya berisi tentang analisis tentang sumber konten, ketersediaan teknologi, serta fasilitas pembelajaran yang dilakukan dengan menggunakan kuesioner melalui google form. Substansi sumber daya ditawarkan kepada mahasiswa dan menjadi pilihan jawaban di kuesioner yang disebar. Responden diberikan link yang terintegrasi ke google 
form, lalu memilih opsi jawaban yang telah disediakan. Adapun hasil analisis kebutuhan kepada mahasiswa secara rinci dapat dilihat pada tabel 2 berikut.

Tabel 2

Analisis Sumber Daya

\begin{tabular}{|c|c|c|c|}
\hline No & $\begin{array}{l}\text { Variabel } \\
\text { Analisis }\end{array}$ & Karakteristik Pebelajar & Persentase \\
\hline & $\begin{array}{l}\text { Sumber } \\
\text { Konten }\end{array}$ & $\begin{array}{l}\text { Substansi konten bahan ajar } \\
\text { tersedia di jurnal, buku, dan } \\
\text { sumber-sumber yang ada } \\
\text { kaitannya dengan materi } \\
\text { perkuliahan }\end{array}$ & $87,03 \%$ \\
\hline & $\begin{array}{l}\text { Ketersediaan } \\
\text { Teknologi }\end{array}$ & $\begin{array}{l}\text { Mahasiswa memiliki } \\
\text { laptop/gadget yang dapat } \\
\text { mendukung pemanfaatan } \\
\text { bahan ajar elektronik }\end{array}$ & $100 \%$ \\
\hline & $\begin{array}{l}\text { Pemahaman } \\
\text { Teknologi }\end{array}$ & $\begin{array}{l}\text { Mahasiswa memiliki } \\
\text { pemahaman terhadap } \\
\text { penggunaan digital } \\
\text { teknologi dalam } \\
\text { pembelajaran }\end{array}$ & $100 \%$ \\
\hline
\end{tabular}

Analisis sumber daya dilakukan dengan cara menyebarkan angket kuesioner kepada responden. Dari hasil analisis diketahui bahwa sebanyak 87,03\% mahasiswa menginginkan substansi konten bahan ajar elektronik tersedia di jurnal, buku, dan sumber-sumber yang ada kaitannya dengan materi perkuliahan, seluruh mahasiswa memiliki laptop/gadget yang dapat mendukung pemanfaatan bahan ajar elektronik, serta seluruh mahasiswa memiliki pemahaman terhadap penggunaan digital teknologi dalam pembelajaran.

\section{Analisis Tujuan Pembelajaran}

Analisis tujuan pembelajaran berisi tentang analisis capaian pembelajaran yang harus ditempuh mahasiswa berdasarkan muatan mata kuliah yang dilakukan dengan breakdown standar kompetensi lulusan. Adapun hasil analisis tujuan pembelajaran secara rinci dapat dilihat pada tabel 3 berikut.

Tabel 3

Analisis Tujuan Pembelajaran

\begin{tabular}{|c|c|c|c|}
\hline No & $\begin{array}{l}\text { Variabel } \\
\text { Analisis }\end{array}$ & Deskripsi & Ket \\
\hline 1 & $\begin{array}{l}\text { Memahami } \\
\text { konsep dasar } \\
\text { pembelajaran } \\
\text { terpadu }\end{array}$ & $\begin{array}{l}\text { Bahan ajar dapat } \\
\text { mendukung pemahaman } \\
\text { terhadap materi } \\
\text { pembelajaran terpadu }\end{array}$ & Sesuai \\
\hline 2 & $\begin{array}{l}\text { Menganalisis } \\
\text { model-model } \\
\text { pembelajaran } \\
\text { terpadu }\end{array}$ & $\begin{array}{l}\text { Bahan ajar dapat } \\
\text { mendukung proses } \\
\text { analisis model-model } \\
\text { pembelajaran terpadu }\end{array}$ & Sesuai \\
\hline 3 & $\begin{array}{l}\text { Mengembangkan } \\
\text { perangkat } \\
\text { pembelajaran }\end{array}$ & $\begin{array}{l}\text { Bahan ajar dapat } \\
\text { mendukung proses } \\
\text { pengembangan perangkat } \\
\text { pembelajaran terpadu }\end{array}$ & Sesuai \\
\hline 4 & Mensimulasikan & Bahan ajar dapat & Sesuai \\
\hline
\end{tabular}

pembelajaran terpadu

membantu mahasiswa

dalam simulasi

pembelajaran terpadu

Analisis tujuan pembelajaran menunjukkan bahwa bahan ajar yang dikembangkan diharapkan dapat mendukung pemahaman terhadap materi pembelajaran terpadu, dapat mendukung proses analisis model-model pembelajaran terpadu, dapat mendukung proses pengembangan perangkat pembelajaran terpadu, dan dapat membantu mahasiswa dalam simulasi pembelajaran terpadu.

Dalam konteks pengembangan suatu produk, analisis kebutuhan merupakan bagian dan langkah yang sangat penting. Seperti dijelaskan (Branch, 2010) bahwa dalam suatu penelitian pengembangan perlu diawali dengan suatu langkah dimana peneliti melakukan analisis kebutuhan sebelum kegiatan pengembangan produk dilakukan, sehingga produk yang akan dikembangkan berangkat dari data hasil interpretasi analisis kebutuhan yang dilakukan diawal. Kegiatan ini sering dimaknai sebagai kegiatan penelitian awal sebelum peneliti menentukan jenis produk yang akan dikembangkan. Artinya analisis kebutuhan merupakan suatu aktivitas mengumpulkan informasi dalam upaya mengambil sebuah keputusan prioritas, untuk mengidentifikasi kebutuhan yang relevan dengan pembelajaran.

Berdasarkan hasil analisis terhadap kebutuhan bahan ajar menunjukkan bahwa mahasiswa lebih cenderung memiliki ketertarikan terhadap bahan ajar yang dapat mendukung pembelajaran online. Hal tersebut disebabkan karena kebutuhan pembelajaran di era pandemi covid 19, dimana pembelajaran mengarah pada pembelajaran online. Bahan ajar yang dikembangkan mengacu pada pengembangan bahan ajar secara elektronik, mahasiswa berpendapat bahwa bahan ajar berbasis elektronik akan memudahkan dalam proses belajarnya karena dapat dilakukan kapanpun dan dimanapun. Bahan ajar yang dikembangkan dengan inovatif dapat mendorong pembelajaran yang efektif dan mandiri (Hobbs, 1987; Wilson, 2018) serta membantu mahasiswa memperoleh suatu keterampilan yang diperlukan dalam pembelajaran (Busstra et al., 2008). Bahan ajar yang baik juga dapat mendukung proses pembelajaran campuran atau lebih dikenal dengan istilah blended learning (Zwart et al., 2017), dimana bahan ajar akan lebih mudah diakses dan dipelajari oleh mahasiswa.

Pada analisis kebutuhan ini, juga didapatkan informasi bahwa mahasiswa berharap dengan adanya bahan ajar dalam bentuk buku elektronik yang dapat memudahkan proses belajar dari rumah. Bahan ajar elektronik memungkinkan mahasiswa mempelajari setiap topik materi pembelajaran secara individu yang sesuai dengan kemampuan dan kompetensinya (Chang, 2006). Selain itu melalui pembelajaran dengan bantuan bahan ajar elektronik ini dapat menambah pengalaman belajar mahasiswa (Roskvist et al., 2020). Bahan ajar yang baik tentunya berisi tentang teori yang akan dipelajari mahasiswa, rangkuman, dan dilengkapi dengan berbagai aktivitas belajar yang dapat dilakukan mahasiswa meski tidak bertemu secara langsung dengan dosen. Pengembangan kebutuhan pembelajaran hendaknya 
memperhatikan karakteristik mahasiswa dari berbagai aspek seperti perkembangan potensinya, kecerdasan intelektual, serta psikologinya (Cahyanto et al., 2018).

Antusiasme mahasiswa dalam menggunakan perangkat digital seperti laptop dan gadget, sangat mendukung pengembangan bahan ajar elektronik. Dengan bahan ajar tersebut mahasiswa tidak kesulitan untuk memanfaatkan dan mempelajarinya, karena ketersediaan perangkat yang dimiliki mahasiswa dapat menampilkan bahan ajar dengan baik. Hal ini juga dapat menunjang pembelajaran online, sehingga dosen dapat memenuhi kebutuhan pembelajaran dengan mengembangkan bahan ajar berbasis elektronik (Cahyanto \& Afifulloh, 2020), penyampaian materi akan lebih bermakna bagi mahasiswa apabila bahan ajar tersebut dilengkapi dengan aktivitas-aktivitas belajar yang dapat dilakukan mahasiswa untuk membangun sebuah pengalaman mandiri walaupun tidak bertatap muka secara langsung dengan dosen.

\section{IV.CONCLUSIONS}

Analisis kebutuhan pengembangan bahan ajar elektronik pada penelitian ini meliputi analisis karakteristik pebelajar, analisis sumber daya, dan analisis tujuan pembelajaran. Analisis karakteristik pebelajar berkaitan dengan pengetahuan awal mahasiswa tentang konten, persepsi terhadap konten, kemampuan awal, motivasi, potensi sistem penyajian, gaya belajar, serta karakteristik kelompok. Analisis sumber daya berkaitan dengan sumber konten, ketersediaan teknologi, serta fasilitas pembelajaran. Analisis tujuan pembelajaran berkaitan dengan analisis capaian pembelajaran yang harus ditempuh mahasiswa.

Hasil analisis karakteristik pebelajar menunjukkan bahwa $87,03 \%$ mahasiswa memiliki pengetahuan terhadap penggunaan bahan ajar elektronik dalam pembelajaran, 94,44\% mahasiswa memiliki pandangan yang positif terhadap pemanfaatan bahan ajar elektronik dalam pembelajaran, $100 \%$ mahasiswa memiliki kebiasaan menggunakan digital resource dalam kehidupan sehari-hari, $100 \%$ mahasiswa memiliki ketertarikan terhadap penggunaan bahan ajar elektronik dalam pembelajaran, serta 94,44\% Memiliki ketertarikan terhadap bahan ajar elektronik untuk menumbuhkan kemandirian belajar. Sedangkan hasil analisis sumber daya menunjukkan $87,03 \%$ mahasiswa mengetahui bahwa substansi konten bahan ajar tersedia di jurnal, buku, dan sumber-sumber yang ada kaitannya dengan materi perkuliahan, $100 \%$ mahasiswa memiliki laptop/gadget yang dapat mendukung pemanfaatan bahan ajar elektronik, dan 100\% mahasiswa memiliki pemahaman terhadap penggunaan digital teknologi dalam pembelajaran.

Selain itu, dilakukan analisis tujuan pembelajaran yang menunjukkan bahwa produk yang akan dikembangkan harus memenuhi beberapa variabel diantaranya (a) dapat mendukung pemahaman terhadap materi pembelajaran terpadu, (b) dapat mendukung proses analisis model-model pembelajaran terpadu, (c) dapat mendukung proses pengembangan perangkat pembelajaran terpadu, dan (d) dapat membantu mahasiswa dalam simulasi pembelajaran terpadu.

Secara keseluruhan berdasarkan data hasil analisis terhadap kebutuhan pengembangan bahan ajar menunjukkan bahwa secara umum mahasiswa memiliki kecenderungan tertarik terhadap bahan ajar elektronik yang dapat digunakan secara fleksibel serta memuat materi secara rinci baik teoritis maupun bahan yang mendukung praktik simulasi mengajar, sehingga dapat membantu memahami materi khususnya pada saat pembelajaran daring.

\section{UCAPAN TERIMA KASIH}

Kami ingin mengucapkan terima kasih kepada ketua program studi Pendidikan Guru Madrasah Ibtidaiyah Fakultas Agama Islam Universitas Islam Malang beserta para mahasiswa yang telah memberikan izin serta dukungan sehingga penelitian ini bisa terlaksana dan dapat terselesaikan dengan baik.

\section{DAFTAR PUSTAKA}

[1] Baloran, E. T. (2020). Knowledge, Attitudes, Anxiety, and Coping Strategies of Students during COVID-19 Pandemic. Journal of Loss and Trauma, $0(0)$, 1-8 https://doi.org/10.1080/15325024.2020.1769300

[2] Branch, R. M. (2010). Instructional Design: The ADDIE Approach (1st ed.). Springer. https://doi.org/10.1007/978-0387-09506-6

[3] Busstra, M. C., Geelen, A., Feskens, E. J., Hartog, R. J. M., \& Van 't Veer, P. (2008). Design and development of digital learning material for applied data analysis. American Statistician, 62(4),

329-339. https://doi.org/10.1198/000313008X368837

[4] Cahyanto, B., \& Afifulloh, M. (2020). Electronic Module (EModule) Berbasis Component Display Theory (CDT) Untuk Matakuliah Pembelajaran Terpadu. JINOTEP (Jurnal Inovasi Dan Teknologi Pembelajaran): Kajian Dan Riset Dalam Teknologi Pembelajaran, 7(1), 49-56. https://doi.org/10.17977/um031v7i12020p049

[5] Cahyanto, B., Akbar, S., \& Sa, C. (2018). Desain Fisik Kelas Berbasis Tema untuk Sekolah Dasar. Pendidikan, 3(2002), 1520.

[6] Chang, C. C. (2006). Development of competency-based web learning material and effect evaluation of self-directed learning aptitudes on learning achievements. Interactive Learning Environments, 14(3), 265-286. https://doi.org/10.1080/10494820600954112

[7] Coughlan, J., \& Swift, S. (2011). Student and tutor perceptions of learning and teaching on a firstyear study skills module in a university computing department. Educational Studies, 37(5), 529-539. https://doi.org/10.1080/03055698.2010.539698

[8] Cuthbertson, B., Socha, T. L., Potter, T. G., Cuthbertson, B., Socha, T. L., \& Potter, T. G. (2007). Journal of Adventure Education and The double-edged sword: Critical reflections on traditional and modern technology in outdoor education Outdoor Education. January 2015, 37-41. https://doi.org/10.1080/14729670485200491

[9] Czajka, C. D., \& McConnell, D. (2019). The adoption of student-centered teaching materials as a professional development experience for college faculty. International Journal of Science Education, 41(5), 693-711. https://doi.org/10.1080/09500693.2019.1578908

[10] Harto, K. (2018). Tantangan Dosen Ptki Di Era Industri 4.0. $\begin{array}{lll}\text { Jurnal Tatsqif, } & 16(1), & 1-15\end{array}$ https://doi.org/10.20414/jtq.v16i1.159

[11] Hills, D., \& Thomas, G. (2019). Digital technology and outdoor experiential learning. Journal of Adventure Education 
and Outdoor Learning, 20(2), 155-169. https://doi.org/10.1080/14729679.2019.1604244

[12] Hobbs, D. J. (1987). Effects of Content Sequencing and Presentation Mode of Teaching Material on Learning Outcomes. PLET: Programmed Learning \& Educational Technology, 24(4), 292-299. https://doi.org/10.1080/0033039870240405

[13] Karademir, T., Alper, A., Soğuksu, A. F., \& Karababa, Z. C. (2019). The development and evaluation of self-directed digital learning material development platform for foreign language education *. Interactive Learning Environments, 0(0), 1-18. https://doi.org/10.1080/10494820.2019.1593199

[14] Marhayani, D. A. (2020). Kemandirian Belajar Mahasiswa PGSD dalam Perkuliahan Secara Daring Pada Masa Pademi Covid-19. JPDI (Jurnal Pendidikan Dasar Indonesia), 5(2), 36. https://doi.org/10.26737/jpdi.v5i2.2156

[15] Murphy, M. P. A. (2020). COVID-19 and emergency eLearning: Consequences of the securitization of higher education for post-pandemic pedagogy COVID-19 and emergency eLearning: Consequences. Contemporary Security Policy, $0(0), \quad 1-14$ https://doi.org/10.1080/13523260.2020.1761749

[16] Putrawangsa, S., \& Hasanah, U. (2018). Integrasi Teknologi Digital Dalam Pembelajaran Di Era Industri 4.0. Jurnal Tatsqif, 16(1), 42-54. https://doi.org/10.20414/jtq.v16i1.203

[17] Roskvist, R., Eggleton, K., \& Goodyear-Smith, F. (2020). Provision of e-learning programmes to replace undergraduate medical students' clinical general practice attachments during COVID-19 stand-down. Education for Primary Care, 00(00), 1-8. https://doi.org/10.1080/14739879.2020.1772123

[18] Thurston, A. (2005). Building online learning communities. Technology, Pedagogy and Education, 14(3), 353-369. https://doi.org/10.1080/14759390500200211

[19] Wilson, M. C. (2018). Crowdsourcing and Self-Instruction: Turning the Production of Teaching Materials Into a Learning Objective. Journal of Political Science Education, 14(3), 400408. https://doi.org/10.1080/15512169.2017.1415813

[20] Zimmerman, W. A., \& Kulikowich, J. M. (2016). Online Learning Self-Efficacy in Students With and Without Online Learning Experience. American Journal of Distance Education, 30(3), 180-191. https://doi.org/10.1080/08923647.2016.1193801

[21] Zwart, D. P., Van Luit, J. E. H., Noroozi, O., \& Goei, S. L. (2017). The effects of digital learning material on students' mathematics learning in vocational education. Cogent Education, 4(1), 1-10 https://doi.org/10.1080/2331186X.2017.1313581 